\title{
PŘÍSPĚVEK K DĚJINÁM BRNĚNSKÉ HUDEBNÍ VĚDY
}

Dostalo se mi neobyčejné pocty, abych svým příspěvkem uvedl letošní první číslo časopisu Musicologica Brunensia. Zajisté se tak stalo díky roku mého narození s pověstnou čtyřkou na konci data, snad to však bylo také proto, že jsem se věnoval hudbě po celý dlouhý život nejenom ze záliby, nýbrž i z profese k prospěchu společnosti.

K hudbě jsem tíhnul od malička. V rodných Košicích jsem se učil hrát na housle někdy od deseti let. Jako zdatný hudební amatér (později i violista) jsem veřejně vystupoval. Navštěvoval jsem koncerty a operní představení. Po svévolném vysídlení (diktátem Vídeňské arbitráže) do Brna v listopadu 1938 jsem navštěvoval reálné gymnázium. Maturoval jsem v červnu 1943, okamžitě jsem však byl nasazen na různých místech do německého zbrojního průmyslu. Již jako gymnazista jsem $\mathrm{k}$ hudebním zálibám brzy přidal četbu knih o hudbě a $\mathrm{v}$ četbě podle možností i za pracovního nasazení pokračoval. Mezi knihami byly i spisy klasiků české hudební vědy, Otakara Hostinského, Otakara Zicha, Vladimíra Helferta. Při četbě čtyř dílů dvořákovské monografie Otakara Šourka ${ }^{1}$ jsem si do zvláštního sešitu opisoval všechny notové př́klady se stručnými komentáři. Seznámil jsem se i s některými pracemi mých budoucích univerzitních učitelů Jana Racka a Bohumíra Štědroně. Mnohé z těchto knih, označených mým podpisem a datem, si uchovávám ve své soukromé knihovně. Četl jsem českou beletrii a poezii i několik filozofických spisů, Rozpravy o metodě René Descarta s doslovem a poznámkami Jana Patočky, ${ }^{2}$ v českém překladu Kantovu Kritiku čistého rozumu, ${ }^{3}$ v níž jsem si spiše listoval, než četl. Pro studium estetiky jsem byl získán Schillerovou Estetickou výchovou, ${ }^{4}$ můj zájem o filozofii prohloubila knižní rozprava

1 ŠOUREK, Otakar. Život a dílo Antonína Dvořáka, 4 svazky. Praha: Hudební matice Umělecké besedy, 1922-1933.

2 DESCARTES, René. Rozprava o metodě, jak správně vésti svůj rozum a hledati pravdu ve védách. Praha: J. Laichter, 1933.

3 KANT, Immanuel. Kantova Kritika čistého rozumu (překlad František Krejčí). Praha: Česká akademie věd a umění, 1930.

4 SCHILLER, Friedrich. Estetická výchova (překlad Josef Hrůša). Praha: Bohuslav Hendrich, 1942. 
Albíny Dratvové Etika tvưrči práce, ${ }^{5}$ též spisy mého budoucího učitele filozofie, Masarykova žáka Arnošta Inocence Bláhy. Četba hudebněhistorických a estetických spisů nabývala převahy nad praktickým muzikantstvím, až nakonec v mých zájmech převládla.

Když se v květnu 1945 znovu otevřely brány vysokých škol, okamžitě jsem požádal tehdejšího docenta hudební vědy Jana Racka, nástupce německými nacisty umučeného Vladimíra Helferta, aby mně dal souhlas $\mathrm{k}$ návštěvě jeho semináře a přednášek. Po celou dobu mých univerzitních studií (1945-1949) až do emeritování (1970) byl profesor Racek mou dobrou duší. Angažoval mne jako vědeckého koncipistu brněnské odbočky Státního ústavu pro lidovou píseň (1949). Doporučil mne rektorovi Ludvíku Kunderovi za pedagoga Janáčkovy akademie múzických umění, na níž jsem vyučoval dějiny hudby první poloviny dvacátého století a teorii lidové písně (1953-1963). Jan Racek mne roku 1963 habilitoval pro oba obory na Filozofické fakultě Brněnské univerzity, jak byla po roku 1948 přejmenována. Pět let jsme pak spolu, učitel a žák, vedli hudebněvědecký seminář (1969).

V těžkých letech komunistické normalizace (1970-1990) jsem převzal po svém učiteli řízení ústavu. Přízni děkanátu a rektorátu se muzikologie vůbec netěšila. Představitelé hlavních oborů (např. někteří historikové) nás považovali za „„̌éngeisty“ a z fakulty by nás byli nejraději vypudili. S malými počty studenti̊, s vymyšlenými fintami jsem udržoval chod a úroveň brněnské muzikologické školy. Nápomocni mně při tom byli především Rudolf Pečman a Jiří Fukač. Uchovávali jsme kontinuitu naší školy s jejími dřivějšími etapami, s Helfertovou meziválečnou etapou a s Rackovou poválečnou etapou. V jednání o zachování ústavu jsme manévrovali i s jeho názvy. V osmdesátých letech, kdy již hrozilo skutečné zrušení hudební vědy, se osvědčilo spojení s dějinami umění a teatrologií. S kamuflovaným názvem „Katedra marxisticko-leninské estetiky“ neměl ústav nic společného. Několik málo studentů později vzpomínalo na přednášky a semináře, které se konaly v duchu svobodné vědy. Jako hmatatelná vzpomínka na tuto dobu zůstaly balíky dopisního papíru, $\mathrm{v}$ jehož levém horním rohu byl vytištěn název Katedra marxisticko-leninské estetiky. Nikdo nás za tuto kamufláž neudal. Balíky dopisních papírů nám pak sloužily několik let za makulaturu.

Čtvrtá etapa téměř staleté existence ústavu již náleží brněnské muzikologické současnosti. Slova se ujala nová generace. Jsem št’asten, že se na mnohostranném dění ústavu mohu podílet speciálními přednáškami i jako školitel doktorandů. Vděčím za to i Petru Mackovi, který již po léta úspěšně spravuje chod ústavu. Jeho bezprostřední předchůdci Mikuláš Bek a Stanislav Tesař působili v úřadu jen krátkou dobu; nevytvořili tak $\mathrm{v}$ dějinách ústavu epochu. S několika novými impulzy přišel jen Jiří Fukač. Stanislav Tesař byl prvním tajemníkem kolokvií, k vykonávání úřadu přednosty Muzea české hudby jezdil do Prahy, a přispěl tak k záchraně památek české hudby. Teprve za Mackova trvalého vedení dosahuje ústav v pevné organizační struktuře na nové obzory. Dnešní počet studentů různé

DRATVOVÁ, Albína. Etika tvưrči práce. Praha: Bohuslav Hendrich, 1941. 
specializace je s minulostí nesrovnatelný. Dovoluji si ovšem položit otázku, zda je to vždy i ku prospěchu muzikologie, která by měla v konečném dopadu moderovat charakter všech zastoupených oborů.

Sám jsem o vědeckost pracoviště usiloval, když na mě za totalitní normalizace po odchodu všech tří profesorů do penze dopadlo v úřadě vedoucího hlavní bř́mě odpovědnosti. Na půdě vědy jsem nalezl oporu v reflektivním Jiřím Fukačovi. Nepřednášel, přijal jsem ho do hudebněvědného semináře. Úzce jsme po léta spolupracovali. Spojovalo nás žákovství u profesorů Racka a Štědroně. V metodologické progresi nás inspirovaly kontakty s evropskou muzikologií, zejména na proslulých brněnských kolokviích. $\mathrm{V}$ té době nás ústřední tiskový orgán KSČ Rudé právo marně mentoroval, abychom se věnovali otázkám socialistické hudební teorie a praxe. Hájili jsme naše pozice.

S Rudolfem Pečmanem jsme asistovali profesoru Janu Rackovi na Mezinárodním hudebněvédeckém kongresu Leoš Janáček a soudobá hudba a dobře jsme si zapamatovali jeho programové progrese. Texty v češtině a světových jazycích jsem připravil $\mathrm{k}$ vydání $\mathrm{v}$ české a cizojazyčné verzi ${ }^{6}{ }^{6}$ pohnuly tehdy i českou hudební vědou, nebot' obsahují vědecká sdělení trvalé ceny. S Pečmanem a Fukačem jsme pak kráčeli v pořádání kolokvií ve šlépějích svého učitelského vzoru, též za direktivní politické normalizace po roce 1970. Vrcholem brněnské kolokvijní éry byl mezinárodní hudebněvědecký kongres UNESCA o Hudbě slovanských národỉ, ${ }^{7}$ o jehož uspořádání nás při nečinnosti pražské muzikologie požádalo Ministerstvo kultury. Z brněnských muzikologických kolokvií jsme každý po svém těžili i ve vlastní práci. Těžili z ní i kolegové z jiných českých a slovenských center, kteří do Brna rádi dojížděli.

Uvedu jen za sebe, jak jsem se v progresi své muzikologie vyvíjel. Vděčím Karlu Steinmetzovi za to, že jako někdejší redaktor pražského nakladatelství Panton vydal svazek mých Muzikologických rozprav ${ }^{8}$ s obsáhlou úvahou z pera Jiř́ho Fukače Když je muzikologie také koníčkem. Zvláště si dovolím zmínit se o těchto rozpravách, psaných ve stylu mého praučitele Otakara Hostinského, poněvadž obsahují v hutném výběru všechny stránky a etapy mé muzikologické zralosti:

V kapitole první K metodologii a teorii hudebni védy to jsou studie: $O$ potřebnosti pojmu styl v hudbě; O slovanské hudbě; Hudebni analýza-základni úkol janáčkovské historiografie; Kategorie hudebně nové z komplexniho teoretického pohledu; O inovacich $v$ hudbě; $O$ významu prózy v hudbě. V kapitole druhé O osobnostech hudebni vědy to jsou studie: Sušilovy Moravské národni písně po stránce metricko-rytmické; Hudebnè-historiografické dílo Otakara Hostinského; Úvaha nad Nejedlého pojetím české hudby 18. století; K významu Helfertových idejí o hudebním klasicismu; Léta brněnského působení Vladimíra Helferta;

Leoš Janáček a soudobá hudba. Mezinárodni hudebně vědecký kongres, Brno 1958, (ed. Jiří Vysloužil). Praha: Panton, 1963.

7

Hudba slovanských národů a její vliv na evropskou hudební kulturu. Hudebněvědné sympozium, Brno 9.10.-13.10. 1978, (ed. Jiř́i Vysloužil). Brno: Česká hudební společnost, 1981. 
Československý kontext muzikologického dila Jozefa Kresánka. V kapitole třetí O osobnostech hudebni tvorby to jsou studie: Ke vztahu slova a tónu u Dvoráka a Janáčka; K otázce nacionálního a kosmopolitního se zvláštním zřetelem k divadlu Bohuslava Martinů; $O$ hudební próze, zvláště u některých expresionistů; Alois Hába; Arnold Schönberg v Brně; Anton Webern a česká hudba.

Většina těchto rozprav vyšla německy, též italsky. Nejstarší je z roku 1970. Seznam těchto rozprav by se slušelo doplnit o řadu knih, o kritickou edici Leoš Janáček. O lidové písni a hudbě, vydanou v Janáčkově archivu, ${ }^{9}$ o dvojí slovenské vydání knihy Hudobníci XX. storočia ${ }^{10}$ o monografii Alois Hába. Život a dílo, ${ }^{11}$ vydanou v pražském nakladatelství Panton, je to první má velká kniha věnovaná tomuto skladateli a teoretikovi. S Jiř́m Sehnalem jsme společně napsali Dějiny hudby na Moravě. ${ }^{12}$ Můj shrnující pohled na Leoše Janáčka jako ojedinělé a jedinečné osobnosti české a světové hudby vyšel knižně pod názvem Leoš Janáček: für Sie poträtiert. ${ }^{13} \mathrm{Z}$ posledních knih přesahuje svým předmětem hranice kontinentu monografie Karel Husa. Skladatel mezi Evropou a Amerikou. ${ }^{14} \mathrm{~V}$ nedávné době vyšly dvě moje knihy, ve vídeňském nakladatelství Böhlau Musikgeschichte Mährens und Mährisch-Schlesiens v redakci Hartmuta Kronese ${ }^{15}$ a v nakladatelství Univerzity Palackého v Olomouci Dvě stě let české hudby na Moravě z iniciativy a $v$ redakci Jana Vičara. ${ }^{16}$

Ve výčtu mých knižních opusů nemůže chybět ani třísvazková monografie $L i$ dová píseň a hudba na Moravě z let 1954-1957, která ležela v rukopisu více než půl století v několika knihovnách. Jejího vydání se jako redaktor iniciativně ujal emeritní ředitel Etnologického ústavu AV ČR Lubomír Tyllner a měla by být snad $\mathrm{v}$ tomto roce vydána.

Vždy jsem se cítil být v hudební vědě (a kritice) spíše solitérem. Málo jsem kompiloval, spíše jsem hledal cesty k poznání nových fakt a interpretací. Někdy jsem však spojil své se svými žáky, takto na Souborném kritickém vydání hudebního díla Leoše Janáčka i se skladatelem a teoretikem Jarmilem Burghauserem

9 JANÁČEK, Leoš. O lidové pisni a lidové hudbě: dokumenty a studie, (ed. Jiří Vysloužil). Praha: Státní nakladatelství krásné literatury, hudby a umění, 1955.

10 1. vydání viz VYSLOUŽIL, Jiří. Hudobníci 20. storočia. Bratislava: Štátne hudobné vydavatel'stvo, 1964; 2. vydání viz VYSLOUŽIL, Jiří. Hudobníci 20. storočia. Bratislava: Opus, 1981.

11 VYSLOUŽIL, Jiří. Alois Hába: život a dílo. Praha: Panton, 1974.

12 SEHNAL, Jiří - VYSLOUŽIL, Jiří. Dějiny hudby na Moravě. Brno: Muzejní a vlastivědná společnost, 2001.

13 VYSLOUŽIL, Jiří. Leoš Janáček: für Sie porträtiert. Leipzig: VEB Deutscher Verlag für Musik, 1981.

14 VYSLOUŽIL, Jiří. Karel Husa: skladatel mezi Evropou a Amerikou. Praha: Akademie múzických umění v Praze, 2011.

15 VYSLOUŽIL, Jiř́i. Musikgeschichte Mährens und Mährisch-Schlesiens vom Ende des 18. Jahrhunderts bis zum Jahr 1945. Wien: Böhlau Verlag, 2014.

16 VYSLOUŽIL, Jiří. Dvě stě let české hudby na Moravě. Olomouc: Univerzita Palackého v Olomouci, 2014. 
jako lektorem nakladatelství Supraphon. Na vysloveně tvưrčí spolupráci se zakládá Slovník české hudebni kultury, jehož redaktorem se stal spolu se mnou Jiř́ Fukač. Náročnou bibliografii ke slovníku převzal Petr Macek. ${ }^{17}$ Tak rozsáhlé dílo, vlastně hudební encyklopedie, je důstojným pokračováním české části Československého hudebního slovníku osob a instituci ${ }^{18}$ Práce na slovníku byly započaty již v sedmdesátých letech, kdy si mě ke spolupráci přizval můj učitel Bohumír Štědroň za dř́ve již zesnulého Graciana Černušáka. Ani Bohumír Štědroň se však nedočkal nástupnického díla. Po tahanicích s Prahou padla všechna tíha na mne. Zabránil jsem předání administrativy slovníku do archivu Českého hudebního fondu, získal od jeho ředitelství nezbytné dotace k pokračování (1982). Mým redakčním partnerem se stal Jiří Fukač, v té době odborný vědecký pracovník ústavu. Deset let jsme úzce spolupracovali, dali společnému dílu pevné základy, $\mathrm{v}$ jeho taxonomii nám pomáhal pražský estetik a teoretik hudby Jaroslav Volek. Nejvíce jsme však profitovali z neformálního (vlastně ilegálního) partnerství s lexikografickou školou univerzity Freiburgu im Breisgau Hanse Heinricha Eggebrechta. $\mathrm{S}$ jeho týmem jsme se scházeli nelegálně ke konzultacím $\mathrm{v}$ mém bytě a na mé chatě. S Jiř́m Fukačem jsem byl i při nepřetržitých starostech o ústav a kolokvia v každodenní komunikaci. Po roce 1990 převzal pracovní iniciativu, zřejmě i z obavy o včasné dokončení a vydání slovníku. Slovník české hudební kultury pak vyšel za spolupráce početného týmu autorů roku 1997 v nakladatelství Editio Supraphon Praha.

Já jsem však své lexikografické ambice kompenzoval samostatně dvoudílným př́ručním hudebním slovníkem značného rozsahu, ve věcné první části o sta heslech, ve druhé jmenné části o tisíci heslech. V obou částech jsem ve výkladu uplatnil systémová hlediska. Dílo vyšlo pod názvem Hudebni slovnik pro každého. ${ }^{19}$ Vděčně vzpomínám nakladatele z Hábova rodiště Vizovice J. V. Rychlíka, který mně dal volnou ruku k uplatnění odborných hledisek (při zachování srozumitelnosti).

Svưj prríspěvek jsem možná pojal poněkud ahistoricky a možná též hodně osobně. Nevzpomínal jsem však pouze na sebe. Snad jsem nezapomněl na nikoho, kdo byl ke mně vstřícný a dokázal ocenit i vlídně mé dílo. Byli to především Jiří Fukač a Rudolf Pečman, jejichž památce věnuji toto skromné vyprávění.

Jiří Vysloužil (28800@mail.muni.cz), Ústav hudební vědy, Filozofická fakulta, Masarykova univerzita, Brno.

17 VYSLOUŽIL, Jiř́i - FUKAČ, Jiří - MACEK, Petr. Slovník české hudební kultury. Praha: Editio Supraphon, 1997.

18 ŠTĚDROŇ, Bohumír - ČERNUŠÁK, Gracián - NOVÁČEK, Zdenko. Československý hudebni slovnik osob a institucí, 2 díly. Praha: Státní hudební vydavatelství, 1963-I, 1965-II. VYSLOUŽIL, Jiří. Hudebni slovník pro každého, 2 díly. Vizovice: Lípa, 1995-I, 1999-II. 


\section{ABSTRACT CONTRIBUTION TO HISTORY OF BRNO MUSICOLOGY}

The text is conceived as a contribution to history of Department of Musicology in Masaryk University in Brno, from point of view of major Czech musicologist and long-time head of this department, professor Jiří Vysloužil who celebrated his 90th birthday last year. The contribution is dedicated to important stages in history of the department, former and current pedagogues as well as to professional scientific activity which was closely connected to the Department of Musicology in Brno not only in the past but also in the present.

\section{Key words}

Brno, musicology, history, musical institutions

\section{Bibliography}

DESCARTES, René. Rozprava o metodě, jak správnè vésti svi̊j rozum a hledati pravdu ve vědách. Praha: J. Laichter, 1933.

DRATVOVÁ, Albína. Etika tvưrči práce. Praha: Bohuslav Hendrich, 1941.

Hudba slovanských národi̊ a její vliv na evropskou hudební kulturu. Hudebněvědné sympozium, Brno 9.10.-13.10. 1978, (ed. Jiří Vysloužil). Brno: Česká hudební společnost, 1981.

JANÁČEK, Leoš. O lidové písni a lidové hudbě: dokumenty a studie, (ed. Jiří Vysloužil). Praha: Státní nakladatelství krásné literatury, hudby a umění, 1955.

KANT, Immanuel. Kantova Kritika čistého rozumu (překlad František Krejčí). Praha: Česká akademie věd a umění, 1930.

Leoš Janáček a soudobá hudba. Mezinárodni hudebně vědecký kongres, Brno 1958, (ed. Jiří Vysloužil). Praha: Panton, 1963.

SEHNAL, Jiří - VYSLOUŽIL, Jiří. Dějiny hudby na Moravě. Brno: Muzejní a vlastivědná společnost, 2001.

SCHILLER, Friedrich. Estetická výchova (překlad Josef Hrůša). Praha: Bohuslav Hendrich, 1942.

ŠOUREK, Otakar. Život a dílo Antonína Dvoř́ka, 4 svazky. Praha: Hudební matice Umělecké besedy, 1922-1933.

ŠTĚDROŇ, Bohumír - ČERNUŠÁK, Gracián - NOVÁČEK, Zdenko. Československý hudebni slovník osob a institucí, 2 díly. Praha: Státní hudební vydavatelství, 1963-I, 1965-II.

VYSLOUŽIL, Jiří - FUKAČ, Jiří - MACEK, Petr. Slovník české hudební kultury. Praha: Editio Supraphon, 1997.

VYSLOUŽIL, Jiří. Alois Hába: život a dílo. Praha: Panton, 1974.

VYSLOUŽIL, Jiří. Dvě stě let české hudby na Moravě. Olomouc: Univerzita Palackého v Olomouci, 2014.

VYSLOUŽIL, Jiří. Hudebni slovník pro každého, 2 díly. Vizovice: Lípa, 1995-I, 1999-II.

VYSLOUŽIL, Jiř́i. Hudobnici 20. storočia. Bratislava: Štátne hudobné vydavatel'stvo, 1964.

VYSLOUŽIL, Jiří. Karel Husa: skladatel mezi Evropou a Amerikou. Praha: Akademie múzických umění v Praze, 2011.

VYSLOUŽIL, Jiří. Leoš Janáček: für Sie porträtiert. Leipzig: VEB Deutscher Verlag für Musik, 1981.

VYSLOUŽIL, Jiří. Musikgeschichte Mährens und Mährisch-Schlesiens vom Ende des 18. Jahrhunderts bis zum Jahr 1945. Wien: Böhlau Verlag, 2014.

VYSLOUŽIL, Jiří. Muzikologické rozpravy. Praha: Panton, 1986. 